\title{
Sree Narayana Movement and Social Transformation of Modern Kerala: A Bird's-Eye View
}

\section{OPEN ACCESS}

Manuscript ID:

ASH-2021-09013914

Volume: 9

Issue: 1

Month: July

Year: 2021

P-ISSN: 2321-788X

E-ISSN: 2582-0397

Received: 20.04.2021

Accepted: 04.06.2021

Published: 01.07.2021

Citation:

Anirudhan, Shaji. "Sree

Narayana Movement and

Social Transformation

of Modern Kerala: A

Bird's-Eye View." Shanlax

International Journal

of Arts, Science and

Humanities, vol. 9, no. 1, 2021, pp. 89-97.

DOI:

https://doi.org/10.34293/

sijash.v9i1.3914

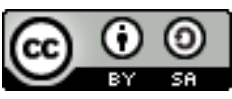

This work is licensed under a Creative Commons Attribution-ShareAlike 4.0 International License

\author{
Shaji Anirudhan \\ Professor of History, University of Kerala, Kerala, India
}

\begin{abstract}
Among the various factors that contributed for the transformation of Kerala into a modern democratic society the role played by Sree Narayana movement was most significant. Realising that the political power was the master key to social progress, the leaders of the movement came into tacit understanding with non Hindus, made permutations and combinations with them to maintain and strengthen their position in the society. Through their protests, incessant conflicts and assertions, they succeeded in transforming the pyramidal social structure of Kerala into pillar structure. From the position of caste victims they could elevate themselves to the makers of their own destinies. They also succeeded in politicising the social relations. The philosophies and pragmatic approaches propounded by Narayana Guru for the material and spiritual advancement of the backward caste people of Kerala was found successful that contributed for the social transformation from structural relations to human relations and from caste hierarchical structure to inter-personal relations.
\end{abstract}

Keywords: Colonial modernity, Missionary intervention, Aruvippuram prathishta, Civic rights movement, Abstention movement, Conversion threat

\section{Introduction}

It is interesting to investigate the various factors that contributed for the progressive transformation of modern Kerala into a democratic society from the clutches of caste and class differences, feudalistic patterns and outmoded customs that instigated the sages like Swami Vivekananda to characterise as land of lunatic asylum. Till the beginning of the 19th century the modern state of Kerala presented a picture of the existence of caste taboos, untouchability, unapproachability, complicated inheritance laws, irrational customs and manners and unscientific land ownership. The Hindu society was pyramidal in structure where the numerically insignificant population enjoyed the privileges where as the non caste Hindus who constituted the rank and file of the society were denied all civic rights. Kerala was the most caste ridden part of India where pollution was observed in its vulgar form. ${ }^{1}$ The Aryanisation brought about chathurvarnya hierarchy in the society, but unlike the greater part of India, below the Brahmins and Ambalavasis or temple servants, all other caste groups were treated outside the pale of chathurvarnya system. In the case of Non Hindus like Christians and Muslims, the caste hierarchy was not numerous. As per the Census report of 1901 there were 192 principal castes and $1070 \mathrm{sub}$ castes among the Hindus where as there were only 14 Christian divisions and 47 Muslim divisions. ${ }^{2}$

1 Puthezhathu Raman Menon. Keralathe Ariyuka (To Know About Kerala), Sulabha Books, 1997, p.13.

2 Bhattacharya. Hindu Castes and Sects, quoted in Ghurye, Caste and Race in India, Popular Prakasham, 1969, p. 12; See also the Census Report 1901. 
In the Kerala society the lower caste people were subjected to slavery, humiliation and exploitation and were forced to live with no voices. They were not permitted to enter into some areas, prevented from constructing big houses, carry umbrellas, wear shoes, use descent languages and study modern science and arts. Their women folk were not permitted to cover the upper parts of their body and wear gold ornaments, but have to use stone chains known then in Malayalam as kallumala. Several feudal taxes including breast tax, hair tax etc. was collected from the lower caste people by the state which has been legitimised by the Brahmin law givers. The lower caste Hindus were neither permitted to enter into the public offices like post office and village office nor walk through the approach roads of the temples due to the obnoxious practice of pollution. All public amenities built out of public funds were reserved for the use of upper castes and hence the lower caste people could not use rest houses, public wells and so on and so forth. A system of forced labour known as uzhiyam and free labour known as viruthy were imposed on the lower caste people. The practice of brahmadeya, agrhara and devadana land grant systems made the socio- economic condition of the higher castes very comfortable. The rulers of the state appeased the higher castes, especially Brahmins through the uttupuras or free feeding houses for the Brahmins and ceremonies like murajapam, thulabharam etc. It was King Marthandavarma, the maker of modern Travancore who introduced the practice of murajapam in 1749. It was a ceremony of chanting verdict manthras which consisted of sahasranamajapam, mantrajapam, murajapam and jalajapam- the whole ceremony lasted for 56 days. Huge amount was spent from the treasury for appeasing the Brahmins who engaged in the murajapam ceremonies.

In practice the socio-economic system that prevailed in Kerala was nothing but theocratic feudalism. The structure and working of the Kerala society was determined by the caste status and not economic status, where the birth not money that determined the status of an individual, a typical pattern that prevailed in the rest of the country. The purity-pollution dichotomy was the core philosophy that ruled the hierarchical division of the Hindu society of Kerala. Every aspect of life was determined by the caste; whether it is political, social, religious or economic and the class division of the society was only a later development. In traditional Hindu society, this 'divine inequality' was held high as the order of the day. ${ }^{3}$ The system that prevailed in the state was like that of the system of slavery practiced in America and apartheid prevailed in African continents. Kumaran Asan, a poet and social revolutionary of Kerala stated that, "the cruelty and ruthlessness shown to the lower castes of Kerala by the higher castes were comparable to the cruelty shown to the aborigines of America by the settlers from Spain. It would have been no wonder if the people of the lower castes decided to leave their villages and go to the forests and live like animals reversing the process described in Darwin's theory of evolution."4 The institutionalised oppression prevailed in the Kerala society was so deep that it was impossible to identify it as oppression.

\section{Winds of Change in Kerala Society}

Towards the second half of the 19th century winds of change began to appear in the Kerala society, due to the growth of national consciousness and colonial interventions. Introduction of English education and intervention of Christian missionaries brought about changes of great magnitude. The emergence of a powerful leadership from among the people, its perception of the situation and the capacity to act accordingly, the formation of a counter ideology, change in the material conditions of production, in certain situations interface with external forces-visa-vis colonial power for instance-may accelerate or even inaugurate the process of change. The social change that took place in Kerala during the19th and 20th centuries was a by-product of all these factors. ${ }^{5}$ The colonial rule was instrumental for the introduction of modern education, modern technology and economic reforms.

3 Genevieve Lemercinier. Religion and Ideology in Kerala, 1990, p. 186.

4 C.P.Sivadasan. "Sree Narayana Guru." Edited by M. Govindan, Kumaran Asan Birth Centenary volume, Sameeksha, 1974, p. 210.

5 J. Prabhash, Affirmative Action and Social Change: Social Mobility of Dalits. Anmol Publications, 2001, pp. 32-33. 
The British as part of their colonial motives like domination of Indian states and spread of Christian religion attempted to expand their political supremacy over the princely states of Travancore and Cochin as well as British Malabar. The capitalist inroads were made into the feudal social structure of Kerala by the British from the second half of the 18th century. They have introduced drastic infrastructural changes in Kerala suitable to the growth of a mercantile economy. ${ }^{6}$ It was with this objective in mind that the British appointed Residents in the Princely states of Travancore and Cochin as a controlling mechanism over the Kings. They have promoted progressive land reforms, changed the agrarian system based on feudalism and advised the Kings to introduce social and economic reforms like abolition of slavery and land ownership rights through the pandarappattam proclamation and jenmi-kudiyan proclamation. Another important offshoot of the colonial intervention was the growth of public sphere which helped the slave castes to develop their public opinion. Emergence of a public sphere can be considered as a facilitating agency for the modern nationalising project. $^{7}$

The missionary works, especially the British and European evangelical missionaries brought about significant impacts in the society. Through the establishment of educational institutions and imparting educational facilities to the poor low caste people, starting printing presses and publishing news papers and magazines and opening hospitals in different places, the missionaries succeeded in making drastic changes in the social fabric of Kerala along with ensuring good number of converts to their faith. It was the work of L.M.S among the Shanars in South Travancore that sparked off the famous controversy in 1835 about the right of Shanar women to wear an upper cloth above the waist which Hindus claimed was the right of high caste women only. ${ }^{8}$ The interventions of the missionaries were instrumental in destabilizing the caste structure in Kerala.

6 George Mathew. Communal Road to Secular Kerala, Concept Publishing Company, 1989, p. 33.

7 P. Sanal Mohan. Modernity of Slavery - Struggles Against Caste Inequality in Colonial Kerala, 2015, p. 11.

8 Louise Ouwerkerk. No Elephants for the Maharaja: Social and Political change in the Princely state of Travancore (1921-1947), Manohar Publications, 1994.
People of Kerala responded differently to the changes brought about by the colonial intervention. The upper caste Hindus had both beneficial and adverse impacts where as to the lower castes it produced great opportunities for their social and economic advancement. A new spirit of enquiry and criticism as well as civic consciousness developed among the lower castes. ${ }^{9}$ The colonial intervention was capable enough to challenge the hierarchical Hindu social system, changing social conception and developing democratic ideals. It contributed for the transformation of family relationships and providing more spaces for representations in educational and representative institutions and government employment. Vivekodayam, the official mouth- piece of the Sree Narayana Dharma Paripalana Yogam argued, "The peace and freedom that we enjoy now are not experienced by us under any other dispensation. The education drives away the darkness hidden in every nook and corner of our country and transforms millions who were forced to live like animals into human beings. The administrative policy of the British has granted us the freedom, which was beyond our reach within the framework of Sublime religion. It has abolished the monstrous practices and corruption and extirpated the fangs of the venomous serpent of the inhuman caste system." $" 10$ Another notable impact of the colonial inroads into Kerala society was the political awakening that developed among various castes and communities. The innumerable studies and census reports released by the British rule helped for the identity formation and caste solidarity among them. The desire for social mobility was articulated through caste groups. Associations sprang up for each and every caste and these associations stood for the social and economic advancement of their members. In those days the socially backward classes had to look to the European masters for the redemption of

9 M.N. Srinivas writes, The lower castes wanted a share in the new opportunities and they were also stirred by new equalitarian winds blowing across India. The movement assumed a particularly vigorous form in Peninsular India where the non Brahmin castes succeeded in obtaining for themselves concessions and privileges; M.N. Srinivas, Social Change in Modern India, Orient Longman, 1972, p. 73.

10 Vivekodayam, Vol. V, nos. 7, 8, 1909, p.3. 
their lost rights as human beings and as citizens. ${ }^{11}$ Further the social and religious reform leaders were largely inspired from the changes brought about by the colonial interventions. It furthered competitive spirit among castes and communities in Kerala and in the long run the communities that took advantages out of modernisation benefited from it and those who lagged behind were necessarily handicapped in various ways.

\section{Emergence of Social Movements in Kerala}

Like the greater part of India, the state of Kerala gave birth to several social reform movements, both reformative and transformative. Such movements were originated and progressed in various parts of the country. But due to the pluralities and diversities of religions and social customs the possibility for a unified reformist or revivalist movement was rather limited. A country-wide organised transformation of Hinduism or Islam would be as miraculous as agreement on a single spoken language for the entire country. ${ }^{12}$ Among the social movements started in India, except the movements of Jyothiba Phule of Maharashtra, and Sree Narayana Guru and Ayyankali of Kerala, all others belonged the higher castes. ${ }^{13}$ Unlike the greater part of India, the social movements that began in Kerala was different because of the peculiar caste-class structure of the region. The peculiarity was that in this region the movements were firstly spearheaded by men belonging to lower strata of Hindu society. The central personages of

11 T.K. Ravindran. Asan and Social Revolution in Kerala, Kerala Historical Society, 1972, p. XXIII;

M.S.A. Rao. Social Movements in India, Vol. I, Manohar Publishers, 1978, p. 209.

12 Charles H. Heimsath. "The Functions of Hindu Social Reformers with special reference to Kerala." The Indian Economic and Social History Review, vol. 15, no. 1, 1978. 13 The leaders of the 19th century reform movement include Rajaram Mohan Roy, Keseb Chandra Sen, Mahadev Govinda Ranade, Dayananda Saraswathi, Ramakrishna Paramahamsa and Vivekananda. Jyothiba Phule was a reformer of Maharashtra who belonged to a low caste family of flower suppliers. He founded the Satya Sodhak Samaj in 1873. For details about his life and work see Rosalind O' Hanhon. Caste Conflict and Ideology: Mahatma Phule and Low Caste Protest in 19th century Western India, Orient Longman, 1985. the movements were not high caste intellectuals inspired by the European Enlightenment but low caste Ezhavas and later Pulayas, Parayas and members of some smaller caste groups. ${ }^{14}$ The state of Kerala before its linguistic reorganisation witnessed revolutionary social movements that touched the higher level of ideology and contributed for the progressive transformation of society into modern democratic society. Even though the first reformer who succeeded in making some influences in the society of Kerala was Vaikunda Swamikal, the Saint and reformer who was instrumental in making revolutionary transformation in the Kerala society was Sree Narayana Guru and the movement that he and his disciples carried on in the fertile soil of Kerala was known as Sree Narayana movement. Their movement came out victorious in setting the base in the society for deconstructing the caste and religious ideology.

\section{Emergence of Sree Narayana Movement}

Sree Narayana Guru who hailed from the Ezhava caste of Hinduism was the pioneering figure of social movement in Kerala. The movement initiated by him was calculated with the objective of social revolution and social transformation using religion as an effective channel. Born in 1856 at Chempazhanthy, Thiruvananthapuram as the youngest son of Madan Asan and Kutty, the first revolutionary act of Narayana Guru was the installation of a Siva idol at Aruvippuram in 1888, breaking the right denied to the non caste Hindus. When his sanskritisation act was questioned by the caste Hindus, his answer was powerful enough to solemn, his opponents. ${ }^{15} \mathrm{It}$ was Dr. P. Palpu of the Ezhava community of Travancore who firstly realized the value of starting an organization for the transformation of society, annihilating the caste taboos and guaranteeing the basic human rights for the downtrodden castes. It was he who provided the necessary background and inspiration for the works of both Sree Narayana Guru

14 Charles. H. Heimsath, op. cit., p. 26.

15 For details about the significance of Aruvippuram Prathishta see Mathrubhumi 16 February 1988; Kerala Kaumudi 15 December 1991; Malayala Manorama 10 February 1988; K.K. Panikker. Sree Narayana Paramahamsan (Biography), Vidyarambhom Press, 1950, pp. 141-42. 
and Kumaran Asan. ${ }^{16}$

Being a victim of the caste tyranny existed in Travancore Dr. Palpu started preparation for an organization for his community men immediately after receiving unsatisfactory response from the government to the Ezhava Memorial submitted under his leadership. He formulated bylaws for an organization named by him as Ezhava Maha Jana Sabha and started campaign among his community along with his close associates. When this initiative failed to achieve its desired goal, he met Swamy Vivekananda at Mysore and sought his advice. Vivekananda advised him the select a saint to spiritualise and industrialise the masses for social transformation because the social reform movement in Indian context could go deep among the masses only if it should have a religious foundation. Dr. Palpu had no other option than to meet Narayana Guru, who had, by this time earned a high reputation as a great sanyasin. Guru who constructed a temple at Aruvippuram after the famous installation of the Siva deity constituted an eleven member committee known as Aruvippuram Vavoottu Yogam to look after the affairs of the temple administration. The temple and its roerties were registered with P.Parameswaran, the brother of Dr. Palpu as its manager. It was P. Parameswaran who facilitated the meeting between Narayana Guru and Dr. Palpu and after initial discussions it was decided to start an organization by the name Sree Narayana Dharma Paripalana Yogam that came into being on 15 May 1903 with Sree Narayana Guru as permanent President, Kumaran Asan as Secretary and Dr. Palpu as Vice President. In order to propagate the ideals of Guru and Sree Narayana Dharma Paripalana Yogam an official mouthpiece was started known as Vivekodayam, a name selected in memory of Swami Vivekanada and started publication with Vivekananda suktham as its caption 'Uthishtatha Jagratha Prapyayan Nibodhitha.'

It was for the propagation of the ethics of Narayana Guru and uplifting all the lower caste people that the SNDP Yogam was founded. Narayana Guru had contributed a lot of ideals and philosophical discourses for humanity irrespective

16 Kerala Kaumudi, 8 January 1972. of caste barriers. ${ }^{17}$ But the Ezhava community that produced the Great Guru largely benefitted out of the pragmatic and spiritual teachings of the Guru. He took initiative in constructing a large number of temples for the lower castes to save them from the exploitation of higher castes, introduced sanskritised form of worship, advocated financial control in the personal and private life and taught the people to abandon outmoded customs and practice reforms. Sanskritisation of the Ezhava community was the first and foremost aim of Guru. At the same time it contained an element of defiance against the caste order in the act of constructing parallel temples. ${ }^{18}$ The practical principles advocated by him were later emulated by the social reformers of other communities of Kerala. The principles and messages of Narayana Guru were a war cry against all kinds of exploitation and a pragmatic solution against a stagnant society. His teachings produced not only spiritual effects but also material impacts. Even though he laid the foundation of temples and muts, the building that came up was one that of social equality. Even though he sowed the seeds of spiritualism, what grew in the field were socio-political rights. ${ }^{19}$

Sree Narayana Guru treated temples as rallying points of solidarity and centres of all round activity. In order to ensure the collective gathering of the people irrespective of caste differences, Narayana Guru exhorted to establish monasteries, schools, lecture halls, banks, dispensaries, libraries, rest houses and gardens in the surroundings of the temples constructed by him. One can witness in him not a mere sanyasin preaching his ideals but a karmayogi propagating pragmatic philosophy of actions. The interventions in Hindu religious affairs made by

17 M. Viswambharan. Narayana Guru (Biography), NBS, 1980, p. 45.

18 During that time avarnas respected the higher class and offered presents to the savarna temples considering it as their dharma. Narayana Guru, after realising the seriousness of the matter, started temple consecration to punish the savarnas and help the low castes; Murkoth Kumaran. "Oru Samudaya Parishkara Margam." Malayala Manorama, Investiture Special Number, 1931.

19 E.M.S. Namboothiripad. "Pakiyathu Adhyatma Chinthayude Vithu, Mulachu Vannathu Samuhya Rashtreeyavakasam." Deena Bandhu, Onam Sree Narayana Jayanti Special, 1972. 
Narayana Guru were a move towards the reforming the religion and not its demolition or annihilation. In that sense Sree Narayana Guru can be hailed as a Hercules who purified Hinduism. ${ }^{20}$ In order to modernize his community men and all those who do not belong to the purview of chathurvarnya system Sree Narayana Guru proposed pragmatic changes in social and economic spheres. He discouraged costly marriage ceremonies and polygamy, suggested inter-dining and inter- marriage, exhorted to abandon the traditional occupation of toddy tapping by the Ezhavas of Kerala and propagated the vedantic teachings in simple and lucid language. His interventions benifitted not only the Ezhava community but several other communities of the state and by emulating his preaching, different castes and communities came up with new organizations and programme of reforms. The social movement started by Guru produced revolutionary changes in the social, economic, political and religious life of Kerala as a whole. S.N.D.P.Yogam and Ezhava community were fortunate to get the services of a group of dedicated young men who spread over the whole areas of Kerala. Prominent among them were Dr.Palpu, Kumaran Asan, Sahodaran Ayyappan, T.K.Madhavan, C.Krishnan, Murkothu Kumaran, Paravur Kesavan Asan, C.R.Kesavan Vaidyar, C.Kesavan, C.V.Kunjuraman, K.R.Narayanan and N.Kumaran. These dealers effectively used their pen and platform for a transitional change in the society, a transition from change resistant sacred outlook to change ready secular outlook. Modern Kerala society witnessed their interventions in all social and political protests for transforming the society from its pyramidal structure to pillar structure and ensure political participation and establishment of democratic institutions because they realized that political power is the master key for social progress.

\section{Role of Sree Narayana Movement in the Protest for Civic Rights}

The self confidence created by Sree Narayana, influence of colonial modernity and the impact of 20 Kerala Kaumudi, 2 January 1972. See also M.C. Joseph. "Adhunika Yugathile Mahanaya Prayogika Thathwajnani." Deena Bandhu, Onam Sree Narayana Jayanti Special, 1962; Vivekodayam Special Supplement, January 1967, p. 170. freedom and revolutionary movements progressed in national and international level had its deep impact on the non Hindus and non caste Hindus of Kerala at the dawn of the 20th century. This led to a new political alliance among the principal communities of Kerala; the Ezhavas, Muslims and Christians who pleaded for the civic rights denied to them by the existing regime. The Non Hindus like Christians and Muslims demanded due representation in the government services including the revenue department where they were misrepresented due to the attachment of that department with devaswoms or temple properties. Christians and Muslims were debarred from the appointment in the Revenue department on religious grounds while the Ezhavas and other low castes on caste grounds. In addition to this demand the non caste Hindus pleaded for entry into all public amenities in the state and recognition as citizens instead of subject people. In the place of the concept of Praja (the subject people) the word Pauran (citizen) got wide currency and consequently Paura Samathva Vadam (Civic Rights) gained significance in Travancore context. ${ }^{21}$

The Civic Rights movement constituted a major chapter in the political history of modern Kerala. The aggrieved communities of Ezhavas, Christians and Muslims demanded the separation of Devaswoms from the land revenue department for ensuring their entry into the services of the land revenue department. More over the Revenue was the most important department of administration and the heads of several non-technical departments were chosen from the higher-grade posts in that department. ${ }^{22}$ The demands for the separation was raised in the popular assemblies like Sree Mulam Popular Assembly, Sree Chitra State Council and Travancore Legislative Council by the representatives of various non Hindus and non caste Hindus. The demands raised in the popular assemblies by M.D.Arumanayakam, C.Thomas, Varkey John, G.Idichandy, Thomas

21 The modern concepts of citizenship and leis size fare were purely western which developed after the French Revolution. The educated Indians also acquainted with these concepts. In Travancore by the beginning of the 20th century the marginalized communities realised that there was politics even in 'wordings'

22 Caste and Citizenship in Travancore, Travancore Civic Rights League, 1919, p. 8. 
Mathai, M.J.Chacko, Kumaran Asan, C.P.Thomas, C.O.Madhavan, K.G.Madhavan, P.N.Ismail Munnaveli, Ousep Avira Tharakan, Jacob Kurien, Mamman Mappilai, Eapen Gee Varghese, K.I.Kochippan Mappilai, Thomas M. Murikal and T.K.Madhavan deserves special mention. For a unified protest the three communities formed a political organization called Civic Rights League or Travancore Paura Sabha in June 1918. ${ }^{23}$ In order to make the agitation more powerful the branches of the organization were created in various parts of the state. T.K. Madhavan, the leader of Sree Narayana Movement utilised the services of the Tiyya Passive Resistance League which he formed in 1918 to strengthen the activities of the Civic Rights League. ${ }^{24}$

The aggrieved communities used their publications to advance their claims. Kerala Kesari published article highlighting the demands of the Civic Rights League in 1920. C.Krishnan, A.Ayyappan, T.K.Madhavan and C.V.Kunjuraman, the leaders of Sree Narayana movement used their publications Mitavadi, Sahodaran, Desabhimani and Kerala Kaumudi respectively for popularizing the Civic Rights movement. The Christian publications like Nasrani Deepika and Malayala Manorama played a crucial role in this respect. Other notable publications that played a significant role in this respect include Vivekodayam, Navajeevan, Sathyanadam, Paschimodayam, Sathyanadakahalam, Rajyasamacharam, Malankara Vijayithan, Malankara Sabha Patrika, Malankara Sabha Mitram, Pauradhvani, Christian Mahilamany, Syrian Church Message, Kottayam Patrika, Dasan, Kerala Dasan, Sathyadeepam, Kerala Katholican, Kerala Mitram, Yuvabharati and Messenger. The Travancore government was forced to concede before the popular demand and hence entrusted

23 The President of the League was E.J. John, High Court Vakil, Thiruvananthapuram. The secretaries were C. Raman Menon, P. Sivaraman, Pathrose Mathai and M. Itticheria. Other prominent leaders include T.K. Madhavan, K.C. Mammna Mappilai and John Chandi; File No. 46/1921, Bundle No. 92, Political Department, KSA, Nalanda, Thiruvananthapuram

24 The Tiyya Passive Resistance League was founded by T.K.Madhavan in 1918 to work for the social upliftment of Ezhavas; S.N.Sadasivan, A Social History of India, APH Publishing Corporation, p. 508.
Krishna Ayyangar, the Forest Settlement Peishkar to study and report on the issue of the separation of Devaswom Department. He recommended the separation of all government and private Devaswoms from the Land Revenue Department including charitable institutions. On the basis of the report a proclamation was made separating the Devaswom from Land Revenue Department on 12 April 1922. Through the separation of Devaswom from the Land Revenue Department, the main obstacle for the employment of the aggrieved communities in the Revenue Department was relieved.

The leaders of Sree Narayana movement struggled for the opening of public amenities before the non caste Hindus. They opposed the installation of pollution board known as 'theendal palakakal' in various parts of the state, prohibiting the movement of the low caste Hindus near the temples. These notice boards defending on the one hand the ritual integrity of the Hindu temples and on the other hand denying an elementary civic right to some sections of the subjects of the state. ${ }^{25}$ It was for getting the rights of the low caste Hindus to move freely through the approach roads of the temples that the famous satyagraha movements at Vaikom, Guruvayur, Suchindram, Thiruvarppu, Ambalappuzha, Kalpathi, Paravur and Kanyakulangara conducted in which the leaderships were taken by T.K. Madhavan and other stalwarts of Sree Narayana movement.

\section{Role of Sree Narayana Movement in the Nivarthana Agitation}

It was for getting adequate representation in the legislative bodies that the aggrieved communities of Ezhavas, Christians and Muslims started the Nivarthana agitation otherwise called Abstention movementin 1930s. Thismovementwasacontinuation of the Civic Rights movement. This movement was started against the legislative reform proclaimed on 28 October 1932 as Regulation II by His Highness Sri Chitra Thirunal Maharaja which provided least representation to the aggrieved communities. The leaders of Sree Narayana movement in association with the Non Hindu organisations like Wajanathul

25 A. Ayyappan. Social Revolution in a Kerala Village: A Study in Culture and change, Asia Publishing House, 1965, p. 134. 
Muhammadiya Association, All Travancore Muslim Service League, Hidayathul Islamiya Sabha, Travancore State Catholic Congress, All Travancore Christian Political Conference, South Travancore Indian Christian Association, Latin Christian Mahajana Sabha, Kerala Christian Service League and All Kerala Catholic Congress and formed a new political organisation known as All Travancore Joint Political Conference or Samyuktha Rashtriya Samiti. They have decided to abstain from the election to the legislative council. Kerala witnessed several meetings, protests, signature campaigns and submission of memorandums during the period of abstention movement. On 13 May 1935 C. Kesavan, the leader of Sree Narayana movement made a provocative speech at Kozhenchery against the Diwan C.P. Ramaswamy Iyer, the brain behind the legislative reforms of Travancore. He satirically argued that with the development of Nivarthana agitation 'The Ninth Celebration began in the Huzur Garbha Griha. ${ }^{26}$ He labelled Sir. C.P. Ramaswamy as 'Jantu'(Creature) and said, "We have to deport that Jantu-I do not say Jantu, but Hindu, beyond Sahyadri and sprinkle the cowdung." ${ }^{27}$ Kesavan was tried and put in jail by the authorities. The situation changed in the state with the vehement protest of the aggrieved communities and the favouarable stand taken by the new Dewan of Travancore Habibulla. Government appointed E. Subramonia Iyer, Retired Principal, Government Law College as Franchise Commissioner on 17 August 1935. The new move was wholeheartedly supported by the aggrieved communities. On the basis of the report of the franchise commissioner reservation of seats were provided in the legislatures for the principal communities of non Hindus and non caste Hindus.

\section{Sree Narayana Movement and the Politics of Conversion}

In Hinduism temples were the visible symbols of religion and in Kerala the low caste Hindus not only denied entry but also prohibited the passage through the approach roads. The innumerable protests and petitions of the people could not create any positive signal from the side of the authorities. The 26 N. Thankappan. "Kesavanum Nivarthana Prasthanavum." Vivekodayam, vol. 3, 1969, p. 80. 27 Ibid. movement for temple entry was started in Kerala by the Ezhava community and leaders of Sree Narayana movement. To begin with Raman Thampi a Judge in the High Court while delivering the presidential address in the Sree Narayana Guru Jayanthi meeting held at Kollam in 1918, made a plea that the Ezhava communities of Travancore should start parallel temples in the state and raise their demand for entry into Hindu temples. Following this C.V. Kunjuraman, leader of Sree Narayana movement wrote an article in the Desabhimani daily in favour of starting temple entry movement. In the popular assemblies the same demand was raised by SNDP leaders like T. K. Madhavan, Kunju Panikker and Chavarkottu Marthandan Vaidyan. T. K Madhavan succeeded in enlisting the support of Gandhi for the temple entry demands of the non caste Hindus of the state. The leaders of Sree Narayana movement like C. Krishnan, Sahodaran Ayyappan and C.V Kunjuraman used the politics of conversion as a threat for conceding the rulers in favour of temple entry. There were occasional cases of conversion from the Ezhavas to Buddhism, Sikhism, Islam and Christianity. For conversion one of the early choices of the Ezhava leaders was Buddhism. Changaranmkulathu Krishnan who owned and edited the news paper Mitavadi presented Buddhism as an anti-thesis to discriminatory Hinduism and made a lot of homework to reproduce the heritage of the Ezhavas to Buddhist religion.

Further he argued that Buddhism was the suitable religion for the Ezhavas for conversion because unlike Christianity and Islam it guaranteed equal treatment to all its followers including converts. ${ }^{28}$ When the movement for conversion to Buddhism was in the air one Sreedharan along with a few others embraced Buddhism in Alapuzha. He set up an organisation called Buddha Mission in Alapuzha and assumed a new name R. Sugathan. C. Krishnan and Ayyappan invited a Budha Bhikshu from Ceylon and arranged all facilities for his stay at Kozhikode.

Sikhism was another option for the Ezhavas to convert. When the conversion propaganda crossed the boundaries of Kerala, the Sikh leaders once again reached Kerala and attempted to convert the Ezhavas to their faith. Later for propagating conversion two Sikh leaders namely Master Thara Singh and 28 Mitavadi, Annual, Calicut, 1927, pp. 92-96. 
Sirdar Lal Singh visited Kerala. They even made attempts to construct few Gurudvaras in Malabar. An Ezhava leader K.C. Kuttan and his few associates embraced Sikhism. Mr.Kuttan assumed a new name Sardar Jaya Singh after his conversion. Islam was another religion opted by the leaders of Sree Narayana movement as part of conversion threat. Mr. K.L. Gauba an Islamic leader was entrusted for opularising Islamic religion among the Ezhavas. But Christianity was the most acceptable religion for the Ezhavas to convert to whom they had more lineages. They reiterated the enormous services rendered by the Christian missionaries for the educational advancement, annihilation of social abuses \& case rigidity. The strong stand for conversion to Christianity was taken by C.V Kunjuraman, under whose initiative the Ezhava leaders met Bishop Moor at Changanassery aramana for studying the Christian practices. At maramon convention he participated and openly declared that the Ezhava community is going to convert to Christianity. More over the SNDP Yogam in its meeting held at Changanassery under the presidentship of Sahodaran Ayyappan on 6 May 1936 the issue of conversion came up for discussion and the decision was taken in favour of the conversion to Christianity. It was at this point that the Travancore Diwan C.P. Ramaswamy Iyer advised the King Chithira Thirunal to issue the Temple Entry proclamation which became a reality on 12 November 1936.

The Sree Narayana movement and its leaders played a crucial role in the struggle for responsible government in Travancore. The decision to form the Travancore State Congress was taken at Thiruvananthapuram. The SNDP Yogam leaders allied with other principal communities against the autocratic rule of Diwan CP Ramasawamy Iyer and popularised the demand for responsible government at national level. An unsuccessful attempt was made on the life of C.P on 26 July 1947. After this incident he relinquished the Diwanship on 19 August 1947 and responsible government was declared in Travancore On the basis of its recommendations of a reform committee constituted, a free election was held in Travancore in February 1948 and the first ministry was formed under Pattom Thanu Pillai.

\section{Conclusion}

Sree Narayana Dharma Paripalana Yogam was pioneer organization that played a conspicuous role in the transformation of Kerala into a modern democratic society. From the position of the caste victims the Ezhava community and other lower caste Hindus could elevate themselves to the makers of their own destinies. They could politicize the social relations for their advantages that resulted in the social change that involved transformation in social, political and economic organization. This phenomenal change occurred in Kerala was through contradictions. The shift of change was from structural relations to human relations or from caste hierarchical structure to inter-personal relations. For achieving this objective the non Hindus and non caste Hindus made various permutations and combinations. The Socio-Religious reform movements, particularly Sree Narayana movement worked for the creation of an honourable identity for the depressed castes, who were mute millions without a voice in the public realm. In the process of identity formation, the reformers did not wish to wean away the untouchable castes from the larger Hindu identity. The identity of caste was by the Non caste Hindus of Kerala as a powerful weapon against internal colonialism built out of caste principles which according to them more dangerous that external colonialism. Thus before political nationalism caste nationalism had taken root especially in the large majority of people of Kerala who remained outcastes and depressed classes. Political liberty for them was a luxury when compared to the necessary social freedom. Even though they were primarily meant for the material and spiritual uplift of the respective social group, they actively put their head into the political affairs of the state because every social issue had at that given period its political undertones. Protest movements were the vehicles through which the backward castes in Kerala attempted to make social transformation in which the movement played the vital role.

\section{Author Details}

Shaji Anirudhan, Professor of History, University of Kerala, Kerala, India, Email ID: shajideepam@gmail.com 